\title{
Root rot of anthracnose mother plants of garden strawberry: morphological and cultural characteristics of the pathogen and the search for effective fungicides
}

\author{
Julia Kashchits*, Galina Yakuba
}

Federal State Budget Scientific Institution «North Caucasian Federal Scientific Center of Horticulture, Viticulture, Wine-making», 39 str. 40 Let Pobedy, Krasnodar, 350901, Russia

\begin{abstract}
On the territory of the Krasnodar region, anthracnose root rot, the causative agent Colletotrichum acutatum Simmonds, is one of the most harmful diseases in the mother plants of garden strawberry. The death of affected plants ranges from 33 to $100 \%$. Purpose of the research was to study the morphological and cultural characteristics of the causative agent of anthracnose root rot in the mother plant of garden strawberries in the region and to assess the effectiveness of fungicides in controlling the pathogen. The studies were carried out at FGBNU SKFNTSSVV in 20182020 using generally accepted techniques. The object of the research is pure cultures of $C$. acutatum. The morphological and cultural characteristics of C. acutatum were studied on three culture media. A high diversity of the identified morphotypes was shown in terms of the size of conidia and conidiophores, the shape and color of apressoria, and the method of formation of acervules. The influence of seven fungicides of various chemical classes on the development of $C$. acutatum spores has been assessed. Under in vitro conditions at the indicated concentrations, the preparations Luna Tranquility, SC $(0,15 \%)$, Sercadis Plus, SC $(0,1$ and 0,15 $\%)$, Strobi, WG (0,05\%), Horus, WG (0,04 \%) and Skor, EC $(0,04$ and 0,05 $\%$ ) completely prevented the formation of fungal spores.
\end{abstract}

\section{Introduction}

Colletotrichum acutatum Simmonds is one of the most pathogenic species of Colletotrichum Corda, affecting a number of agricultural crops in tropical, subtropical and temperate regions, however, it has the greatest economic importance for the main host plant - garden strawberry (Fragaria ananassa Duch) [ 1-4]. As established by foreign and domestic scientists, the disease is due to the fact that after penetration into the plant, the pathogen stops its

\footnotetext{
*Corresponding author: kashitx2012@yandex.ru
} 
development until a certain period, and the symptoms of infection can appear for several years $[2,5,6]$. It was with these asymptomatic plants that the rapid spread of anthracnose took place. Due to its negativity, C. acutatum is included in the quarantine list of the countries of the European Community, its import and distribution with plant products is prohibited [7, 8]. In the Krasnodar region, the disease poses a serious danger: the death of plants in uterine plantings is $33-50 \%$, in years with abundant precipitation - up to $70-100 \%$ [6]. However, on the territory of the Russian Federation, there is no use of fungicides against the causative agent of anthracnose main rot. In this regard, it is relevant to study the morphological and cultural functions of the pathogen of the anthracnose root rot in the region, as well as the development of an effective pathogen; at the first stage, the primary screening of fungicides is carried out. It is carried out by the in vitro method using pure cultures. The objective of the research was to study the morphological and cultural characteristics of the causative agent of anthracnose main rot of strawberries in the uterine plantations of the Krasnodar Territory and to evaluate the effectiveness of fungicides in vitro in controlling the pathogen.

\section{Materials and research methods}

The studies were carried out in 2018-2020. at the Federal State Budgetary Scientific Institution "North Caucasian Federal Scientific Center for Horticulture, Viticulture, Winemaking" (Federal State Budgetary Scientific Institution «North Caucasian Federal Scientific Center of Horticulture, Viticulture, Wine-making») in the laboratory for the protection and toxicological monitoring of perennial agrocenoses. The object of the study was pure cultures of the fungus $C$. acutatum - the causative agent of strawberry root rot. Isolation of isolates from the affected tissue of the strawberry horns was carried out according to the generally accepted methods with laying in a humid chamber and on potato sucrose agar (PSA). The description of the cultural characteristics of the isolates was carried out on the 10th day of the growth of colonies. The study of the morphological features of the pathogen was carried out for 35 days on potato agar (PA), potato sucrose agar (PSA), potato glucose agar (PGA) [2, 8-13]. The effect of chemical fungicides on the development of pathogen spores was carried out by applying a drop of spore suspension to the dry residue of the preparation with the studied concentration. The repetition is five times. The sprouted conidia were counted every other day.

\section{Results and its discussion.}

We studied 110 samples of the garden strawberry roots from the mother plants of the Krasnodar region and isolated 53 isolates. It was found that the obtained isolates differ in cultural characteristics, which made it possible to divide them into three morphotypes (Table 1). In isolates of morphotype III, the colony diameter is $13,9-16,9 \%$ larger than in isolates of morphotypes I and II. In all isolates of II and III morphotypes, the colonies had an elevated profile with an aerial mycelium height of $2,0 \mathrm{~mm}$; in isolates of morphotype $\mathrm{I}$, the height was $3,0 \mathrm{~mm}$. The most variable features were the height of the center of the colony, as well as the width of the edge of the colony. The growth rate in isolates of morphotype III was the highest - 12,1-12,7 mm / day, in isolates of morphotypes I and II - average and amounted to 10,4$10,7 \mathrm{~mm} /$ day. The color of the reverseum of the isolates varied from salmon to dark brown with a violet tint.

The main traits for identifying C. acutatum are the size of the conidia, the presence of setae, and the amount of acervula production. In the Krasnodar population of the pathogen, differences between the isolates in terms of morphological characteristics were recorded. Thus, morphotypes differ in the size of conidia: in isolates assigned to morphotype I, the size 
of conidia is mean $\pm \mathrm{SD}$ (range of values within) $=15,0 \pm 2,1 \times 5,0 \pm 0,3 \mu \mathrm{m}$, in isolates of morphotype II - mean $\pm \mathrm{SD}=12,5 \pm 2,3 \times 4,2 \pm 0,5$, in isolates of morphotype III - mean \pm $\mathrm{SD}=13,9 \pm 3,2 \times 4,8 \pm 0,8 \mu \mathrm{m}$.

Table 1. Cultural traits of morphotypes of the Krasnodar population Colletotrichum acutatum Simmonds

\begin{tabular}{|c|c|c|}
\hline $\begin{array}{c}\text { Isolate, } \\
\text { aversum / reversum }\end{array}$ & Cultural trait & Feature variant \\
\hline \multicolumn{3}{|c|}{ Morphotype I } \\
\hline & Colony diameter & $79 \mathrm{~mm}$ \\
\hline & Height & $3,0 \mathrm{~mm}$ \\
\hline & Colony center & bumpy, dense, gray $\mathrm{d}=3,0 \mathrm{~mm}, \mathrm{~h}=5,0 \mathrm{~mm}$ \\
\hline & Texture & Vaty-clumpy, dense \\
\hline & Mycelium color & pale gray with a white tint \\
\hline & Colony edge & smooth, ragged $\mathrm{B}=5,0 \mathrm{~mm}$ \\
\hline & Reverse & $\begin{array}{l}\text { heterogeneous, salmon, with concentric zones, white } \\
\text { edge }\end{array}$ \\
\hline \multicolumn{3}{|c|}{ Morphotype II } \\
\hline & Colony diameter & $77 \mathrm{~mm}$ \\
\hline & Height & $2,0 \mathrm{~mm}$ \\
\hline & Colony center & bumpy, dense gray with a pink tint, $\mathrm{d}=3,3 \mathrm{mм}, \mathrm{h}=2,0 \mathrm{мм}$ \\
\hline & Texture & flat, even \\
\hline & Mycelium color & white with a pale pink tint, dense \\
\hline & Colony edge & even, white, ciliate short, $\mathrm{B}=2,0 \mathrm{~mm}$ \\
\hline & Reverse & heterogeneous, with concentric zones, edge white \\
\hline \multicolumn{3}{|c|}{ Morphotype III } \\
\hline & Colony diameter & $90 \mathrm{~mm}$ \\
\hline & Height & $2,0 \mathrm{~mm}$ \\
\hline & Colony center & $\begin{array}{lllll}\begin{array}{l}\text { bumpy, } \\
\mathrm{h}=7,0 \text { мм }\end{array} & \text { dense, } & \text { gray, } & \mathrm{d}=2,8 & \text { мм, } \\
\end{array}$ \\
\hline & Texture & heterogeneous \\
\hline & Mycelium color & pale pink with a grayish tint \\
\hline & Colony edge & heterogeneous, mainly subaerial, air, $\mathrm{B}=11-16 \mathrm{~mm}$ \\
\hline & Reverse & $\begin{array}{l}\text { heterogeneous, brown with a pale purple tint, with } \\
\text { yellowish irregular zones inside the colony }\end{array}$ \\
\hline
\end{tabular}

Legend: $\mathrm{d}$ - diameter; $\mathrm{h}$ - height; $\mathrm{B}$ - width

Isolates of morphotypes I and II were distinguished by short conidiophores, 4-20 x 2,55 and 2,5-7,5 $\mu \mathrm{m}$ in length, respectively. In isolates of morphotype III, conidiophores were of two types: short - 3-20,5 $\mu \mathrm{m}$ and long - 28,3-63,5 $\mu \mathrm{m}$. Also, differences between the morphotypes were revealed in the way of the formation of acervules in culture. In isolates of I and III morphotypes on all nutrient media, substrate acervules were formed on the 3-4th day. In isolates of morphotype II on PGA and PSA, deep and surface acervules were formed on days 1-3, while on PA, substrate acervules were formed on the 4th day. The onset of 
conidiogenesis in the isolated isolates on all substrates was recorded on the $3 \mathrm{rd}$ day. The formation of apressoria in isolates of morphotype I on PA and PSA was noted on the 23rd day, on the PGA - on the 31st day. In isolates of morphotype II, apressoria were formed on PA on the 17th day, on the PA and PGA on the 20th day. In isolates of morphotype III, the formation of appressoria was established on the PA on the 31st day, and on the PSA and PGA on the 21 st day. The color of the apressoria in the isolates varied from light brown to brown, and their shape varied from ellipsoidal to round with smooth edges.

Based on the results obtained, it can be noted that $C$. acutatum in the mother plant of garden strawberries from Krasnodar region is characterized by high diversity: the selected morphotypes differ in the size of conidia and conidiophores, in the shape and color of apressoria, in the way of formation of acervules in culture, but do not differ in the type of conidia and mycelium.

As a result of laboratory screening, it was found that the drugs Luna Tranquility, SC 0.15 $\%$, Sercadis Plus, SC 0.1 and $0.15 \%$, Strobi, WDG 0.05\%, Chorus, WDG $0.04 \%$, Skore, EC 0.04 and $0.05 \%$ with the indicated concentrations prevent the development of pathogen spores (Table 2).

Table 2. The effect of drugs on the development of spores Colletotrichum acutatum Simmonds

\begin{tabular}{|c|c|c|c|c|c|c|}
\hline \multirow[b]{2}{*}{ Fungicide } & \multirow[b]{2}{*}{ Active ingredient } & \multirow[b]{2}{*}{$\begin{array}{l}\text { Concentr } \\
\text { ation by } \\
\text { preparati } \\
\text { on, } \%\end{array}$} & \multirow[b]{2}{*}{$\begin{array}{l}\text { Number } \\
\text { of } \\
\text { germinat } \\
\text { ed } \\
\text { spores,\% }\end{array}$} & \multirow[b]{2}{*}{$\begin{array}{l}\text { Biologic } \\
\text { al } \\
\text { efficacy, } \\
\%\end{array}$} & \multicolumn{2}{|c|}{$\begin{array}{l}\text { Growth tubule } \\
\text { formation }\end{array}$} \\
\hline & & & & & $\begin{array}{l}\text { number } \\
\text { of } \\
\text { disputes } \\
\text { with a } \\
\text { growth } \\
\text { tube, } \% \\
\end{array}$ & $\begin{array}{l}\text { length, } \\
\mu \mathrm{m}\end{array}$ \\
\hline \multirow{3}{*}{$\begin{array}{l}\text { Luna } \\
\text { Tranquility, SC }\end{array}$} & \multirow{3}{*}{$\begin{array}{l}375 \quad \mathrm{~g} \quad / \mathrm{L} \\
\text { pyrimethanil }+125 \mathrm{~g} \\
/ \text { L fluopyram }\end{array}$} & 0.08 & 34.8 & 66.2 & 34.8 & $2.5-7.5$ \\
\hline & & 0.1 & 15.1 & 83.6 & 15.1 & 2.5 \\
\hline & & 0.15 & 0 & 100 & - & - \\
\hline \multirow{3}{*}{$\begin{array}{l}\text { Sercadis Plus, } \\
\text { SC }\end{array}$} & \multirow{3}{*}{$\begin{array}{l}75 \mathrm{~g} \mathrm{/} 1 \text { of flux- } \\
\text { pyroxade }+50 \mathrm{~g} / 1 \text { of } \\
\text { difenoconazole }\end{array}$} & 0.08 & 6.9 & 92.5 & 6.9 & 2.5 \\
\hline & & 0.1 & 0 & 100 & - & - \\
\hline & & 0.15 & 0 & 100 & - & - \\
\hline Bellis, WDG & $\begin{array}{l}252 \mathrm{~g} / \mathrm{kg} \text { boscalid }+ \\
128 \mathrm{~g} / / \mathrm{kg} \\
\text { pyraclostrobin }\end{array}$ & 0.1 & 16.3 & 82.3 & 11.9 & $2.5-20.0$ \\
\hline \multirow[t]{3}{*}{ Strobe, WDG } & \multirow{3}{*}{$\begin{array}{l}500 \mathrm{~g} / \mathrm{kg} \\
\text { kresoxim-methyl }\end{array}$} & 0.02 & 29.3 & 68.2 & 18.0 & $2.5-7.5$ \\
\hline & & 0.03 & 19.1 & 79.2 & 15.4 & 2.5 \\
\hline & & 0.05 & 0 & 100 & - & - \\
\hline \multirow[t]{2}{*}{ Chorus, WDG } & \multirow[t]{2}{*}{$750 \mathrm{~g} / \mathrm{kg}$ cyprodinil } & 0.03 & 5.4 & 94.1 & 5.4 & 2.5 \\
\hline & & 0.04 & 0 & 100 & - & - \\
\hline \multirow[t]{4}{*}{ Skor, EC } & \multirow{4}{*}{$\begin{array}{llll}250 & \mathrm{~g} & / & 1 \\
\text { difenoconazole } & \end{array}$} & 0.02 & 14.5 & 84.2 & 9.4 & $2.5-7.5$ \\
\hline & & 0.03 & 7.3 & 92.0 & 6.3 & 2.5 \\
\hline & & 0.04 & 0 & 100 & - & - \\
\hline & & 0.05 & 0 & 100 & - & - \\
\hline \multirow[t]{2}{*}{ Zato, WDG } & \multirow{2}{*}{$\begin{array}{l}500 \underset{\text { gystrobin }}{\mathrm{g} / \mathrm{kg}} \text { triflo- } \\
\text { xysto }\end{array}$} & 0.015 & 83.6 & 9.2 & 17.4 & $2.5-15.0$ \\
\hline & & 0.025 & 67.7 & 26.4 & 25.1 & $2.5-20.0$ \\
\hline Control & distilled water & - & 92.1 & - & 9.3 & $7.5-20.0$ \\
\hline
\end{tabular}

The fungicides Chorus, WDG at a concentration of $0.03 \%$, Sercadis Plus, KS $0.08 \%$, Skore, EC 0.02 and $0.03 \%$, Strobi, WDG $0.03 \%$, Luna Tranquility, SC $0.1 \%$ and Bellis, WDG $0.1 \%$ showed somewhat lower, but rather high efficiency in preventing spore germination. The drugs Strobi, WDG at a concentration of $0.02 \%$ and Luna Tranquility, SC at a concentration of $0.08 \%$ were not effective enough. On the other hand, Zato, WDG at 
concentrations of 0.015 and $0.025 \%$ did not affect the growth of the pathogen spores.

At lower concentrations, the tested drugs suppressed the development of spores weaker: Luna Tranquility, SC (0.08 and $0.1 \%)$, Sercadis Plus, SC (0.08 \%), Chorus, WDG (0.03\%) and Skore, EC $(0.03 \%)$ - at the stage of formation of the sprout tube, Strobi, WDG $(0.02$ and $0.03 \%)$ - at the stage of formation of conidia, Skore, EC (0.02 and $0.03 \%)$ - at the stage of formation of apressoria, Bellis, WDG (0.1\%) and Zato, WDG (0.015 and $0.025 \%)$ - at the stage of mycelium formation.

\section{Conclusions}

Thus, for the causative agent of anthracnose root rot C. acutatum, 53 isolates were obtained in the mother plant of garden strawberries in the Krasnodar region and three morphotypes were isolated, which differ in the size of conidia and conidiophores, the shape and color of the apressoria, the way of formation of acervules in culture, which indicates a high diversity of the fungus in region.

As a result of the primary screening of fungicides for pathogen control, their optimal concentrations were determined depending on the stage of fungal development. Luna Tranquility, SC, registered for use on strawberries, should be used in concentrations of 0.08 $0.1 \%$ before infection penetrates the plant, and after infection in a concentration of $0.015 \%$. In the case of registration for the use of the remaining tested fungicides in the mother plant of garden strawberries, it is advisable to apply them according to the following regulations: before the infection penetrates into the plant Bellis, WDG in a concentration of $0.1 \%$, Strobi, WDG and Skore, EC in concentrations of 0.02-0.03\%, Sercadis Plus, SC at a concentration of $0.08 \%$, Chorus, WDG at a concentration of $0.03 \%$; after the penetration of infection into the plant Sercadis Plus, SC at concentrations of 0.1-0.15\%, Strobi, WDG at a concentration of $0.05 \%$, Chorus, WDG at a concentration of $0.04 \%$, Zato, WDG at concentrations of $0.04-$ $0.05 \%$.

\section{References}

1. U. Damm, R. Baroncelli, L. Cai, Y. Kubo, R. O'Connell, B. Weir, K. Yoshino, P.F. Cannon, IMA 1(2), Fungus, 161-165 (2010). https://doi.org/10.5598/imafungus.2010.01.02.08

2. Yu. P. Kashchits. Fruit growing and viticulture of South Russia. 54(6), 174-182 (2018). https://doi.org/10.30679/2219-5335-2018-6-54-174-182

3. H. El Kaissoumi, N. Mouden, M. Chliyeh, R. Bankirane, A. Ouazzani Touhami, A. Douira, Acta Phytopathologica et Entomologica Hungarica, 53(2), 143-161 (2018). https://doi.org/10.1556/038.53.2018.008

4. E. J. Calleja, B. Ilbery, N. J. Spence, P. R. Mills, Plant Pathol., 62(2), 266-278 (2012). https://doi.org/10.1111/j.1365-3059.2012.02647.x

5. N. A. Ward, J. R. Hartman, Plant Pathol. Fact Sheet, PPFS-FR-S-05 (2012). https://plantpathology.ca.uky.edu/files/ppfs-fr-s-05.pdf

6. S. Bost, R. Allen, Agricultural Extension Service, E12-2015-00-035-02 (2010). https://trace.tennessee.edu/cgi/viewcontent.cgi?article=1071\&context=utk_agexgard

7. P. Talhinhas, C. Mota-Capitão, S. Martins, A.P. Ramos, J. Neves-Martins, L. GuerraGuimarães, V. Várzea, M.C. Silva, S. Sreenivasaprasad, H. Oliveira H. Plant Pathol., 60(3), 483-495 (2011). https://doi.org/10.1111/j.1365-3059.2010.02397.x 
8. N. A. Holod, Yu. P. Kashchits, E. A. Dobrenkov, L. G. Semenova, Fruit growing and viticulture of South Russia, 51(3), 140-148 (2018). https://doi.org/10.30679/2219-5335$\underline{2018-3-51-137-145}$

9. Y. V. Tsvetkova, A. A. Kuznetsova, Plant Health and Quarantine, 1(1), 34-42 (2020). https://www.researchgate.net/publication/341945904_Conventional and modern meth ods for the diagnosis_of_Colletotrichum fungi on_garden_strawberry_Fragaria anan assa

10. R. Baroncelli, A. Zapparata, S. Sarrocco, S. A. Sukno, C.R. Lane, M.R. Thon, G. Vannacci. E. Holub, S. Sreenivasaprasad, PLOS One, 10(6), e0129140 (2015). https://doi.org/10.1371/journal.pone.0129140

11. D. D. De Silva, P. W Crous, P. K. Ades, P. W. J. Taylor. Fungal Biol. Rev., 31(3), 155168 (2017). https://doi.org/10.1016/j.fbr.2017.05.001

12. U. Damm, P. F. Cannon, J. H. C. Woudenberg, P. W. Crous, Stud. Mycol., 73, 37-113 (2012). https://doi.org/10.3114/sim0010

13. A. Ashraful, K. A. Sanjoy, A. Mahtalat, Asian J. Plant pathol., 11, 102-117 (2017). https://doi.org/10.3923/ajppaj.2017.102.117

14. P. Talhinhas, C. Mota-Capitão, S. Martins, A.P. Ramos, J. Neves-Martins, L. GuerraGuimarães, V. Várzea, M.C. Silva, S. Sreenivasaprasad, H. Oliveira, Plant Pathol., 60(3), 483-495 (2011). https://doi.org/10.1111/j.1365-3059.2010.02397.x

15. G. Polizzi, D. Aiello, V. Guarnaccia, A. Vitale, G. Perrone, G. Stea, Plant Disease, 95, 1588 (2011). https://doi.org/10.1094/PDIS-07-11-0567 